\title{
Facial Soft Tissue in Subjects with Class II and Class III Facial Deformities. Preliminary Results
}

\author{
Tejido Blando Facial en Sujetos con Deformidad Facial \\ Clase II y Clase III. Resultados Preliminares
}

Sergio Olate ${ }^{*, * * * * *}$; Mario Cantín ${ }^{*, * *}$; Bélgica Vásquez ${ }^{* * * *}$; Mariano del Sol ${ }^{*, * *}$ \& Márcio de Moraes Ma** $^{* * *}$

OLATE, S.; CANTIN, M.; VASQUEZ, B.; DEL SOL, M. \& DE MORAES, M. Facial oft tissue in subjects with class II and class III facial deformities. Preliminary results. Int. J. Morphol., 32(3):1022-1025, 2014.

SUMMARY: Class II and class III skeletal anomalies require treatments that are both esthetic and functional, so the purpose of this investigation was to study the relationship between facial soft and hard tissues of patients with class II and class III deformities in the lower third of the face. A descriptive study was designed which included class II subjects with a SNB angle less than $78^{\circ}$ and class III with a SNA angle less than $80^{\circ}$. The soft tissue width was analyzed in relation to the Pg point, A point, B point, and upper and lower incisor cervical points. The naso-labial angle and interincisal angle were also analyzed. The studies were done using cone beam computerized tomography and analyzed with the software Simplant O\&O (Materialise, Belgium). The results revealed similarities in the measurements of the facial width soft tissues with differences of less $1 \mathrm{~mm}$ in the Pg point, A point, B point, upper incisor point; the greatest differences were observed between the two groups in thelower incisor cervical point, with almost $5 \mathrm{~mm}$ difference in tissue size. The naso-labial angle also presented differences between the two groups, being more closed in the class III than in the class II subjects (approximate difference of $6^{\circ}$ ). It can be concluded that there are minimal differences in the soft tissue width in class II and class III subjects; other parameters can be analyzed to search for differences that influence treatment planning and strategies for these patients.

KEY WORDS: Facial deformity; Facial morphology; Orthognatic surgery.

\section{INTRODUCTION}

Different types of studies have been used to analyze facial morphology, establishing parameters and conditions that associate some facial deformities with their morphological patterns (Opdebeeck et al., 1978; Wolford et al., 1978). Conditioners of classifications such as class II or class III establish clear connections that define maxillary and facial positions as well as treatment options.

The relationship between soft and hard tissues has been studied with some methodologies where it has been determined that $3 \mathrm{D}$ volumetric studies represent the best analysis conditions, although with no significant differences when compared to the 2D studies (Cheung et al., 2011). Most of the proposed analyses have shown variations in the results, indicating that the soft tissues present various positions in relation to the position of the facial bones.

All analyses associated with the morphological and therapeutic study of alterations of the facial skeleton must focus on soft tissues, since this is the area where the facial changes and modifications of a certain treatment will be seen (Joss et al., 2010). Therefore, establishing the real fields of analysis from among the different anomalies could suggest treatment orientations for planning facial modification surgeries.

The purpose of this investigation was to establish the characteristics of hard and soft tissues in subjects with a diagnosis of class II and III dentofacial anomalies in the lower third of the face.

\section{MATERIAL AND METHOD}

Was realized an imaging study on subjects with class II and III facial alterations. All the subjects signed an informed consent to participate in this study. Subjects included were candidates for orthognatic surgery to correct

\footnotetext{
* Division of Oral and Maxillofacial Surgery \& CEMYQ, Faculty of Dentistry, Universidad de La Frontera, Temuco, Chile.

** Center for Biomedical Research, Universidad Autónoma de Chile, Temuco, Chile.

**** Division of Oral and Maxillofacial Surgery, State University of Campinas, Piracicaba, Brazil.

***** Universidad de Tarapacá, Arica, Chile.
} 
class II and class III facial anomalies. Inclusion criteria for class II subjects were a SNB angle less than $78^{\circ}$ and an overjet greater than $3 \mathrm{~mm}$; inclusion criteria for class III subjects were a SNA angle less than $80^{\circ}$ and a negative overjet considered from $-2 \mathrm{~mm}$. Subjects with other skeletal anomalies, in combination with the class II or class III alteration, such as anterior open bite, facial asymmetries and vertical alterations comprising short and long face syndromes were excluded from the study. Subjects having experienced previous facial surgeries, fractures or pathologies requiring surgical resolution also were also excluded.

The subjects underwent a clinical examination prior to the taking of records to define the conditions of the disease. Then cone beam computerized tomography (CBCT) imaging was used, where maximum intercuspidation was maintained in a stable position. The PlanMeca ${ }^{\circledR}$ (Korea) unit was used for this.

The image was processed using the software Simplant O\&O (for Intel X86 Platform V3.0.0.59, 2013 Materialise Dental n.v., Belgium), where the lateral $\mathrm{x}$-ray image was extracted and the contrast and brightness were adjusted to obtain the best image. The image was then magnified $4 \mathrm{X}$ to take the linear measurements, taking care to ensure that all the measurements were parallel to one another. All the measurements began at a point designated in the most anterior area of the bone tissue (radiopaque area) and ended in the most anterior sector of the soft tissue margin (Figures 1 and 2). The measurements were taken from the Pg point, $\mathrm{A}$ point, B point and the cervical points of the upper and lower incisors; the naso-labial angle and the interincisal angle were also established (Figs. 1 and 2). All the measurement were in parallel to the Frankfurt plane.

Each measurement was taken on two separate occasions at a minimum of a 1-week interval in order to study the error of the measurements; if one deviated from the expected norm, a third measurement was taken. All the measurements were taken by the same observer. The data were analyzed descriptively as this study is a comparative analysis of the facial morphology of subjects with class II and class III facial anomalies.

\section{RESULTS}

Twenty-eight subjects, 14 with class III and 14 with class II facial anomalies were analyzed. In the class II group, six subjects were female and 8 were male; in the class III group, nine were male and five were female. The average age of class II subjects was 19.6 years and of class III subjects 18.3 years.
The analyses showed differences at skeletal level between the class II and class III subjects; in addition a trend was observed toward dental compensations in both groups. The overjet characteristics reflect that the observed skeletal alterations at dental level had no major impact, with the exception of one class II subject who presented an overjet of $+8.1 \mathrm{~mm}$. The class II subjects presented an anterioposterior relation of $+6.6 \mathrm{~mm}$, whereas the class III subjects presented an average relation of $-3.9 \mathrm{~mm}$.

The bone soft tissues in the mandibular region revealed similar measurements between the class II and class III groups. In the analysis of the A point, minor variations were also found. The result of the measurements of the lower cervical point reveals average differences close to $5 \mathrm{~mm}$ between the two groups. The naso-labial angle, by contrast, was increased in the class II subjects $\left(113.42^{\circ}\right)$, while in class III subjects this angle was smaller $\left(107.24^{\circ}\right)$, showing a difference of $6.18^{\circ}$ between the measurements. All the results are shown in Table I.

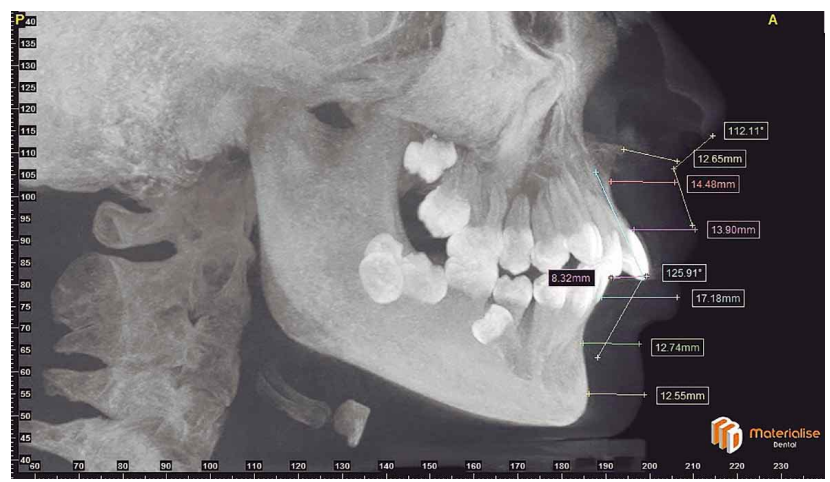

Fig. 1. Image of the analysis performed on facial class II subjects. The eversion produced in the lower lip can be explained by compression from the upper incisor; the records generated in the image can also be seen (Simplant O\&O).

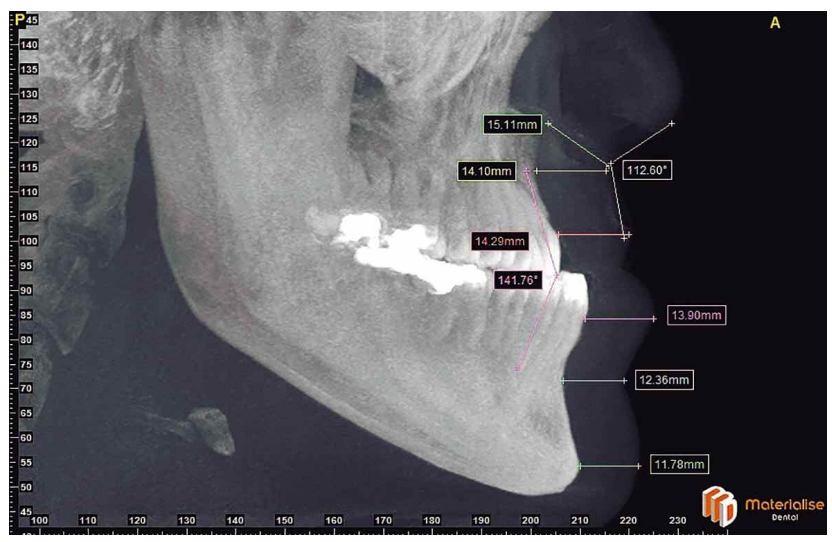

Fig. 2. Image obtained from the software Simplant O\&O for the analysis of class III subjects; the numerical records of each measurement are shown. All the measurements are parallel to one another. 
OLATE, S.; CANTIN, M.; VASQUEZ, B.; DEL SOL, M. \& DE MORAES, M. Facial oft tissue in subjects with class II and class III facial deformities. Preliminary results. Int. J. Morphol., 32(3):1022-1025, 2014

Table I. Relationship observed in Class II and Class III Subjects.

\begin{tabular}{|c|c|c|c|c|c|}
\hline \multirow{2}{*}{ Group } & \multicolumn{2}{|c|}{ Class II } & \multicolumn{2}{|c|}{ Class III } & \multirow{2}{*}{$\begin{array}{c}\text { Differences Class II-III } \\
(\mathrm{mm})\end{array}$} \\
\hline & $X(\mathrm{~mm})$ & $S D(m m)$ & $X(m m)$ & $S D(m m)$ & \\
\hline Pg Point & 11.41 & 4.33 & 11.77 & 2.79 & 0.36 \\
\hline B Point & 11.76 & 1.3 & 11.86 & 1.83 & -0.10 \\
\hline Low IC Cervical Point & 15.14 & 1.28 & 10.50 & 1.78 & 4.64 \\
\hline Upper IC Cervical Point & 11.36 & 1.59 & 11.75 & 1.65 & -0.39 \\
\hline A Point & 13.09 & 1.62 & 13.75 & 1.64 & -0.66 \\
\hline Naso-Labial angle & $113.42^{\circ}$ & $7.9^{\circ}$ & $107.24 \mathrm{o}$ & $8.97^{\circ}$ & $6.18^{\circ}$ \\
\hline Interincisive angle & $127.44^{\circ}$ & $9.19 \circ$ & 136.48 o & $9.80^{\circ}$ & $9.04^{\circ}$ \\
\hline Overjet & 6.66 & 2.9 & 3.92 & 2.43 & --- \\
\hline
\end{tabular}

$\mathrm{X}=$ average $\mathrm{SD}=$ standard deviation.

With respect to the qualitative analysis of the subjects, in all of them precise skeletal relationships were observed, where the class III subjects had retroposition of the maxilla and the class II subjects had retroposition of the mandible, characteristics of both anomalies.

\section{DISCUSSION}

Anomalies of facial skeletal development have been studied previously by some authors with promising work, where subjects' skeletal morphology with different anomalies was analyzed (Opdebeeck et al., 1978; Wolford et al., 1978), determining in detail characteristics of angles and distances that may better represent each alteration.

The results of this study represent a part of the analyses conducted on class II and class III subjects to identify the best study patterns and thus the best options for planning corrective surgery of the facial skeleton. Results from previous investigations by Pozzer et al. (2009) showed an absence of significant differences between class II and class III subjects when proportional measurements were taken of the mandibular morphology. This is consistent with other studies that analyze different morphological elements of the mandible (Cantín et al., 2013; Olate et al., 2013; Zapata et al., 2014). Our results suggest minimal differences in the size of soft tissues associated with the lower third of the face.

Another study has recently been appeared that analyzes the skeletal facial morphology and soft tissues with 3D technology, concluding that the sharpness of the results is similar in both studies. Although 3D technology could optimize some study parameters and surgical planning, our results are totally applicable to clinical practice. Nevertheless, these data must be studied with caution, since studies based on cephalometric X-ray images have noted the deficiencies in evaluating structures in 2D and undertaking surgeries in 3D (Katsumata et al., 2005).

Naini et al. (2012) reported that harmony and consideration of beauty is highly influenced by the soft tissue relations in the lower third of the face; in their study, they performed a profile analysis of different subjects, concluding that in all the observations, the subjects with a convex profile (increased chin projection) presented the worst beauty indicators, whereas the subjects with a straighter profile had better beauty indicators. If it is considered that genioplasty is one of the most relevant cosmetic procedures for the lower third of the face, the results from this investigation may impact on the preoperative valuation of the procedure (Park et al., 2013).

Among the considerations of this study, it is worth noting that the dental points were not analyzed to evaluate soft tissue position because physiological compensations can modify the dental position and thus the soft tissue position. Additionally, one of the major variations observed in this study is in the soft tissue position in relation to the lower IC cervical point, where the class II subjects had an average of $15.44 \mathrm{~mm}$ and class III subjects $10.5 \mathrm{~mm}$; these $5 \mathrm{~mm}$ of difference can be justified by the presence of the retracted mandible, causing with it the pressure of upper incisors on the lower lip, leading to muscular eversion and with it the increased anteroposterior dimension of the sector (Farznegan et al., 2013).

Another aspect of this study lies in the difference in the naso-labial angle, where the class II subjects presented a more open angle compared to the class III subjects, who had a more closed angle. This condition is justified in the position that the anterior nasal spine (ANS) occupies in the two types of deformities: in class III subjects, where deficiencies are seen in the anteroposterior development of the maxilla, the ANS is more towards the posterior and thus the support of the base of the nose is also more posterior, so that the naso-labial angle tends to decrease in such subjects; in class II subjects there is an inverted relationship that produces angles close 
to normal or more esthetically pleasing (Mommaerts \& Moerenhout, 2011).

The retroposition of the ANS causes some subjects to visualize the nasal alteration with the downturn of the nasal tip as an important element in their cosmetic assessment; previous studies have shown the great variability of the pyriform aperture in class III subjects and thus also the variability in the position of cartilages and muscles, demonstrating that the deflection of nasal partition is a common situation in subjects with a class III skeletal anomaly (Olate et al., 2014).

In conclusion, there are minimal differences in soft tissue width when class II and class III subjects are examined. With these data, new morphometric methodologies can be oriented to establish the conditions and singularities of these skeletal anomalies for the different conditions of positional anomaly of facial bones.

OLATE, S.; CANTIN, M.; VASQUEZ, B.; DEL SOL, M. \& DE MORAES, M. Tejido Blando Facial en Sujetos con Deformidad Facial Clase II y Clase III. Resultados Preliminares. Int. J. Morphol., 32(3):1022-1025, 2014.

RESUMEN: Las anomalías esqueletales de clase II y clase III requieren tratamientos que asocian estética y función. El objetivo de esta investigación fue estudiar la relación entre tejidos blandos y duros faciales de pacientes con clase II y clase III facial, a nivel del tercio inferior facial. Se diseño un estudio descriptivo donde se incluyeron sujetos clase II con un ángulo SNB menor de $78^{\circ}$ y clase III con un ángulo SNA menor de $80^{\circ}$. Se analizó el ancho de tejidos blandos en relación a los putos Pg, punto A, punto B, y puntos cervicales de dientes incisivos maxilar y mandibular; también se analizaron los ángulos nasolabial e interincisivo; los estudios se realizaron en tomografía computadorizada cone beam y analizados en el software Simplant O\&O (Materialise, Belgium). Los resultados demostraron semejanzas en las mediciones obtenidas en el ancho facial de tejidos blandos con diferencias menores a 1 mm en los puntos Pg, punto A, punto B y cervical incisivo maxilar; en relación al punto cervical del incisivo mandibular se observaron las mayores diferencias entre ambos grupos, cercanas a $5 \mathrm{~mm}$ de diferencia de tamaño en los tejidos; el ángulo nasolabial también presento diferencias entre ambos grupos, siendo en los sujetos clase III mas cerrado que en sujetos clase II (diferencia aproximada de $6^{\circ}$ ). Se puede concluir que existen mínimas diferencias en el ancho de tejidos blandos en sujetos de clase II y clase III; otros parámetros pueden ser analizados para búsqueda de diferencias que influyan en planificaciones y estrategias terapéuticas para estos sujetos.

PALABRAS CLAVE: Deformidad facial; Morfología facial; Cirugía ortognática.

\section{REFERENCES}

Cantín, M.; Salgado, G.; Inzunza, O.; Inostroza, V.; Errázuriz, M. J.; Pavez, C. \& Fuentes, R. Direct Morphometric Evaluation of Condylar Asymmetry on Human Mandibles. Int. J. Morphol., 31(4):1401-6, 2013.

Cheung, L. K.; Chan, Y. M.; Jayaratne, Y. S. \& Lo, J. Three-dimensional cephalometric norms of Chinese adults in Hong Kong with balances facial profile. Oral Surg. Oral Med. Oral Pathol. Radiol. Endod., 112(2):e56-73, 2011.

Farzanegan, F.; Jahanbin, A.; Darvishpour H, \& Salari, S. Which has a greater influence on smile esthetics perceptions: teeth or lips? Iran. J. Otorhinolaryngol., 25(73):239-44, 2013.

Joss, C. U.; Joss-Vassalli, I. M.; Bergé, S. J. \& Kuijpers-Jagtman, A. M. Soft tissue profile changes after bilateral sagital split osteotomy for mandibular setback: a systematic review. J. Oral Maxillofac. Surg., 68(11):2792-801, 2010.

Katsumata, A.; Fujishita, M.; Maeda, M.; Ariji, Y.; Ariji, E. \& Langlais, R. P. 3DCT evaluation of facial asymmetry. Oral Surg. Oral Med. Oral Pthol. Oral Radiol. Endod., 99(22):212-20, 2005.

Mommaerts, M. Y. \& Moerenhout, B. A. Ideal proportions in full face front view, contemporary versus antique. J. Craniomaxillofac. Surg., 39(2):107-10, 2011.

Naini, F. B.; Donaldson, A. N.; McDonald, F. \& Cobourne, M. T. Assesing the influence of lower facial profile convexity on perceived attractiveness in the osthognathic patient, clinician, and layperson. Oral Surg. Oral Med. Oral Pathol. Oral Radiol., 114(3):303-11, 2012.

Opdebeeck, H.; Bell, W. H.; Eisenfeld, J. \& Mishelevich, D. Comparative study between the SFS and LFS rotation as a possible morphogenic mechanism. Am. J. Orthod., 74(5):509-21, 1978.
Park, J. Y.; Kim, M. J. \& Hwang, S. J. Soft tissue profile changes after setback genioplasty in orthognathic surgery patients. J. Craniomaxillofac. Surg., 41(7):657-64, 2013.

Olate, S.; Cantín, M.; Alister, J. P.; Uribe, F.; Navarro, P.; Olate, G. \& Moraes, M. Relationship Between Condylar Size and Transverse Facial Asymmetry in Subject with Condylar Hyperplasia. Int. J. Morphol., 31(3):937-41, 2013.

Olate, S.; Cantín, M.; Vasquez, B. \& Olate, G. Structure of the Nose in Patients with Class III Facial Deformities. Int. J. Morphol., 32(1):334-8, 2014.

Pozzer, L.; Olate, S.; Asprino, L. \& de Moraes, M. Are there Differences in the Mandibular Morphometry in Patients who are Candidates for Orthognathic Surgery? Part 1: Influences of Facial Class. Int. J. Morphol., 27(3):751-6, 2009.

Wolford, L.; Walker, G.; Schendel, S.; Fish, L. \& Epker, B. N. Mandibular deficiency syndrome. Oral Surg. Oral Med. Oral Pathol., 45(3):329-48, 1978.

Zapata, S.; Medina, H.; Saravia, D.; Navarro, P. \& Olate, S. Morphometric Analysis of the Mandible in Patients with Facial Asymmetry Associated to Condylar Hyperplasia. A Panoramic Radiography Study. Int. J. Morphol., 32(1):161-5, 2014.

Dirección para Correspondencia:

Prof. Dr. Sergio Olate

División de Cirugía Oral y Maxilofacial

Universidad de La Frontera

Claro Solar 115, Oficina 414-A

Temuco

CHILE

Email: sergio.olate@ufrontera.cl

Recibido : 11-04-2014 Aceptado: 09-06-2014 